\title{
THE „CANON PROVIDER" STARTS HIS CAREER - GENERAL JÓZEF DWERNICKI AND THE CAVALRY BATTLE AT STOCZEK (14 FEBRUARY 1831) ${ }^{1}$
}

\author{
Sebastian Bartos, Ph.D., Assistant Professor \\ Dr. John P. Dunn, Professor \\ Valdosta State University, USA
}

„To arms! To arms! The Russians are killing us!” Junior army officers and college students raced through the streets of Warsaw shouting these words on the night of 29 November 1830. This was the start of the Noc listopadowa (November Night), and included fires, assassinations, street fighting, and tremendous confusion for the Kingdom Of Poland. ${ }^{2}$

A compromise resulting from divergent needs of great powers at the Congress of Vienna, it was an autonomous part of the Russian Empire from 1815-1830. This marriage between Poles, whose political traditions stressed limits on royal authority, and Russians who lived under Romanov autocracy, was at the best, a challenging relationship. It might have worked as Tsar Aleksandr I had a reputation for reform, and an interest in constitutions. Unfortunately he drifted off to mysticism after 1816, allowing General Aleksey Arakchevyev to initiate policy. So Russia chaffed under the Arakcheevschina, while stress was also evident in the

1 Drs. Michał Kopczyński and Jarosław Czubaty from Uniwersytet Warszawski and Dr. Bolesław Orłowski from Instytut Historii Nauki PAN, provided valuable advice and bibliographic assistance. We also appreciate Łukasz Sobechowicz and his friend Ariel, who took us to visit the Stoczek battlefield. The good was made better by their collective help; the bad remains the sole property of Bartos and Dunn.

2 For more on the "November Evening," see John Dunn, „The November evening': The Warsaw uprising of November 1830," in Journal of Slavic Military Studies Vol. 16 (2003) No. 3: 126-135. 
Kingdom of Poland. ${ }^{3}$ Thaddeus Kościuszko, who had fought with the Americans against George III, then returned home to direct the 1794 uprising, complained to Thomas Jefferson on 1 April 1816, ,.... constitutional government, liberal and independent, plus the liberation of our wretched peasants...all disappeared like smoke."

The "hero of two nations" would have found Aleksandr's brother, Nikolai I, equally disappointing. Reacting to the Decemberist mutiny that sought to halt his 1825 coronation, the new Tsar and King of Poland clamped down on dissenters. Police raids, censorship, exile or long prison sentences exacerbated anti-Romanov opinions among Polish notables. Historian Norman Davies asserts, "It was Nicholas I who turned even pro-Russian conservatives into active rebels." Nikolai, who viewed rebels as „.... a species of animal between man and beast, something undesirable and unfortunately, all too real," cared nothing for the opinions of the intelligentsia, and continued to stamp out dissent, at home, and in the Kingdom of Poland. ${ }^{6}$

Then, as General Klemens Kołaczkowski remembered the summer of 1830, news of French and Belgian revolutions ,...fell on Warsaw like a lightning bolt."' Highly flammable junior officers, university students, and disgruntled artisans, needed but a single spark to get red hot, and the government provided such with orders to mobilize the Polish Army for restoring the European status quo. ${ }^{8}$

3 Artilleryman and martinet, Aleksey Arakcheyev was Aleksandr's favorite. Schnitzler said he ,....joined the crafty severity of the priest to the sombre [sic]cruelty of the oriental vizier." J. H. Schnitzler, Secret History of the Court and Government of Russia (London: Bentley, 1847), Vol. I, pp. 383-384.

4 Cited in Jacek Jedruch, Constitutions, Elections and Legislatures of Poland, 1493-1993 (New York: Hippocrene Books, 1998), pp. 211-212. See also Harold Nicolson, The Congress of Vienna: A Study in Allied Unity, 1812-1822 (Grove Press, 2001), pp. 172-179.

5 Norman Davies, God's Playground: A History of Poland, 1795 to Date (Columbia University Press, 2005), Vol. II, p. 238.

6 Cited in Nicholas Riasanovsky, Nicholas I and Official Nationality in Russia, 18251855 (Berkeley: University of California Press, 1959), p. 229, n. 89.

7 Klemens Kołaczkowski, Wspomnienia Jenerała Kelensa Kołaczkowskiego (Krakow: Spółka, 1901), vol. 3, p. 133.

8 Wacław Tokarz, Sprzysięźenie Wysockiego i Noc Listopadowa (Warsawa: MON, 1980), p. 69. See also Marek Tarczynski, „Le Rôle de l’Armée dans le Développement Social de la Pologne dans les Années 1807-1831," in Eugeniusz Koz/owski, L'Armée aux Époques des Grandes Transformations Sociales, (Varsovie, 1980), pp. 44-45. 
The November Evening, despite a dose of Clausewitzian friction, tossed Romanov authorities out of Warsaw, or assassinated them on the street like General Maurycy Hauke, whose body featured 19 bullet holes. Eyewitness Roman Sołtyk explained this was ,...the prompt and terrible justice of the people." ${ }^{\prime 9}$ Nikolai, whose brother Konstantin barely escaped a similar fate, was enraged. When the conspirators were revealed as junior officers and academics, with no long term plans, conservative nationalists took control and attempted to negotiate a settlement with the Tsar. His only offer was clemency in exchange for complete surrender. This was not acceptable to Warsaw, and so the November Night morphed into the November Insurrection - a full-fledged war between Poland and Russia. ${ }^{10}$

A war between the Kingdom of Poland, which was smaller than the Napoleonic Grand Duchy of Warsaw, and the Russian Empire seems ludicrous and many Russian and not just a few Polish generals from 1830 shared this impression. Yet it turned out to be a hard fought campaign, one that taxed Russian resources, revealing, as the Crimean War did on a grander a scale, that the army of Nikolai I was far from perfect. ${ }^{11}$

It was a military machine trying to serve too many masters. Massive parades featuring complex drills that had little purpose on the battlefield were one trademark, along with cruel discipline as well as a demand for blind obedience. Then there were the military colonies, where the state attempted to create agricultural centers run by soldier-farmers, but ended up with the worse of both worlds. Tsardom also needed many soldiers for internal security and to protect

9 Roman Soltyk, La Pologne. Précis Historique, Politique et Militaire de sa Révolution, (Paris, 1833), vol. I, pp. 62.

10 „Chłopicki to Nikolai, Warsaw, 10 December 1830,"in Michał Rostworowski (ed.), Dyaryusz Sejmu $z$ R. 1830-1831, (Cracow, 1907), vol. II, pp. 180-182. Nikolai, in a note reproduced on p. 187, responded that clemency was possible, but any further negotiations were „....an unpardonable weakness and needless on my part." Only a few English-language monographs cover the November Insurrection: S. B. Gnorowski, Insurrection of Poland in 1830-1831 and the Russian Rule Preceding It Since 1815, (London, 1839); Józef Hordynski, History of the Late Polish Revolution and Events of the Campaign, (Boston, 1833) and R. F. Leslie, Polish Politics and the Revolution of 1830, (London, 1956).

11 For an excellent introduction, consult John S. Curtis, The Russian Army Under Nicholas I, 1825-1855 (Duke University Press, 1965). See also Frederick W. Kagan, The Military Reforms of Nicholas I (New York: St. Martin's Press, 1999), who argues Nicholas learned from failure, and established traditions that allowed for a much better Russian Army in the $1869 \mathrm{~s} / 70 \mathrm{~s}$. 
the frontiers from disgruntled rivals like Iran or the Ottoman Empire; neighbors defeated by Russian arms in 1828 and 1829. Cholera was about to kill over 100,000 Russians, and the army was needed to man quarantine stations.

Under these circumstances, they performed better than expected. Nikolai's soldiers demonstrated courage and perseverance securing victories in the Caucasus and Balkans, but also exposed problems in training, marksmanship, plus logistical defects. They also lacked reserves, mainly from the state's exclusive reliance on serfs to fill the enlisted ranks. This in turn demanded Russia keep a massive standing army; 800,000 men in 1816. Assignant rubles could paper over this problem for awhile, but their decline in value in relation to gold was astronomical in the early nineteenth century. Perennially short of funds, this made it even easier to avoid costly training exercises, especially if these might conflict with the Romanov mania for parades. ${ }^{12}$

The Russian soldiers poised to invade Poland were trained to fight by the book, move ponderously, favor the bayonet over musketry and above all, avoid initiative. The writers' favorite example of Russian generals' excessive zeal for following regulations comes from 1831. At the start of the campaign, a large group of cavalry was stopped by a Polish infantry company holding a bridge. Hours went by before a Tsarist infantry unit arrived. Even though several regiments could have dismounted, and employed carbine fire to dislodge the bridge guard, this was not attempted as regulations said nothing about fighting dismounted, and advised against charging infantry guarding a bridge! ${ }^{13}$

This is not to say that all advantages lay with the Poles. Russian armies were much more numerous than the opposition, who never fielded more than 60,000 troops. Their gunners were very good, cavalry numerous, and the infantry, even if unimaginative, were steadfast. Their record fighting Bonaparte in 1812-

12 Kagan, Military Reforms..., pp. 10-12, 15. See also Alexander Britts, „Reserves under Serfdom? Nicholas I's Attempts to Solve the Russian Army's Manpower Crisis of 1831-32," in Jahrbücher für Geschichte Osteuropas Vol. 51 (2003) No. 2: 185-196; and Alan Ferguson, The Russian Military Settlements, 1810-1866 (Yale University Press, 1953).

13 John S. Curtis, The Russian Army..., p. 134. 
1815 was certainly impressive, and as Frederick the Great put it..."It is easier to kill Russian soldiers than to defeat them."14

Russian problems played out from the very start of the November Insurrection. Crushing the revolution quickly required mobilization of armies in White Russia and Lithuania. Invading via the Ukraine might have been easier except those troops were recovering from service against the Turks in 1828-29. Commanding the invasion was Hans Karl Friedrich Anton von Diebitsch. One of many foreign officers in Tsarist service, he joined the Semenovsky Life Guard Regiment in 1801, fought in most of the campaigns against Bonaparte, and through a combination of zeal and bravery, was major general by 1812 . His successful campaign against Turkish defenses in the Balkans provided noble title and promotion to Field Marshall. ${ }^{15}$

Diebitsch, directed 114,000 men in eleven separate columns for an invasion of Poland. Expecting little resistance, he gave but three weeks to cross the Bug River at Nur, march on Warsaw, then crush the rebellion. Recent bad harvests, plus lack of funds reduced his army's bread and meat rations by half, and allowed but two cups of vodka per week! Not a good start as slow moving infantry marched through cold weather on a poor road net. ${ }^{16}$

Then nature turned against Diebitsch. Common knowledge holds that "General Winter" serves in the Russian Army, but he must have been AWOL in February 1831 , when temperature went from $-22^{\circ} \mathrm{C}$ to $4^{\circ} \mathrm{C}$ in the space of a week, creating an early thaw. This was disaster of the Field Marshal's strategy, which counted on frozen ground for more rapid movement. Now the regions many rivers, streams,

14 Cited in H. M. Scott, The Emergence of the Eastern Powers, 1756-1775 (Cambridge University Press, 2011), p. 49.

15 Russians called him Diebitsch „Zabalkansky” for his success against the Turks. See Belmont [pseud. Heinrich A. Schuemberg], Hans Carl Friedrich Anton, Graf von DiebitschSabalkanski, kaiserl. russischer Feldmarschall, neben Russlands vorzüglichsten Feldherren; nach mitgetheilten Familien-Nachrichten dargestellt, (Dresden: Arnoldischen, 1830).

16 A. Puzrevskii, Wojna Polso-Rossyjska 1831 Roku. Trans. P. J. Bykowski (Warszawa: Tygodniowego, 1888), p. 41. Written by an eminent military historian and member of the Imperial General Staff, this work came out in several Russian and Polish editions, along with a German translation. Still one of the best histories to date. His Polish counterpart, who scrved as Quartermaster-General during the revolt also produced a superior, albeit sometimes opinionated history. Ignacy Prądzyński, Pamietnik Historyczny $i$ Wojskowy o wojnie PolskoRosyjskiej w roku 1831 (Petersburg: K. Grendy-Szyńskiego, 1898), Vol. I, pp. 28-29. 
ponds and marshy grounds dramatically reduced the rate of march, or eliminated options by now impassible terrain. Compounding the issue, there were still plenty of ice floes to make river crossing longer and dangerous, while cold-damp weather dispirited the invaders. The Russian advance had to focus on the Brest to Warsaw road. This required diligence as first the Russians had to cross the Bug, which could provide Polish commanders with a chance for mischief against partially deployed units. ${ }^{17}$

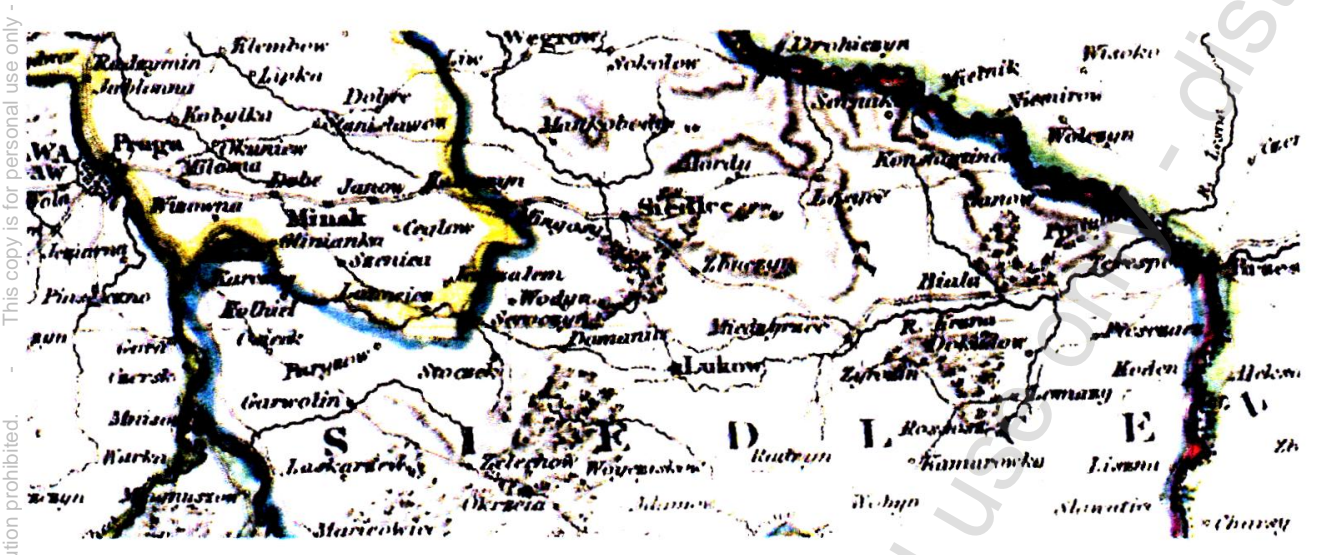

Source: Poland Map, Society for the Diffusion of Useful Knowledge, London 1832.

Map showing Stoczek's place in relation to the Brześć to Warsaw road

Working from interior lines, Poles could strike isolated Russian units, or raise partisan forces to attack Tsarist supply columns. Diebitsch had to proceed with caution, but not too slowly, as every extra day allowed the rebels to mobilize more soldiers who were based in well-supplied towns, while Russian troops lacked shelter and were rapidly consuming their rations. As his hungry men requisitioned food from local farmers with little to spare, this made it guerilla actions even more likely, forcing Diebitsch to deploy garrisons to protect his rear. ${ }^{18}$

On 9 February, the Field Marshal created flank guards to cover his main force on the Brest-Warsaw road. The Second Cavalry Division, commanded by General

17 Puzrevskii, Wojna Polsko-Rossyjska..., pp. 28-29. See also Józef Hordynski, History of the Late Polish, pp.91-93.

18 John S. Curtis, The Russian Army, pp. 77-78; Puzrevskii, Wojna Polsko-Rossyjska..., p. 38. 
Friedrich Caspar von Geismar scouted to the southl and finding no enemy forces, dispersed to search for partisans, supplies, and to find shelter for men and horses. These actions helped generate the first major battle of the November Insurrection. ${ }^{19}$

Von Geismar was part of a tightly knit Germanricadre that held considerable influence in the early Nineteenth Century Russia Army. ${ }^{20}$ Born in Westphalia, he served in Austria's elite Deutschmeister Infantry Regiment, then transferred to Russian service in 1805. By 1813, he was a colonel commanding a Cossack Regiment. Back in Russia, Geismar crushed the last of the Decemberist rebels at Kovalivka (15 January 1825), but it was triumphs against the Turks in 1828-29 that secured promotion to Lieutenant General. ${ }^{21}$

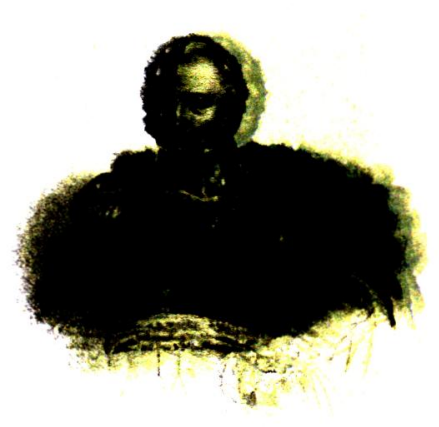

Source: 19th Century Print, John P. Dunn Collection

General Dwernicki from a contemporary print

A very different Napoleonic veteran was about to cross swords with von Geismar. Józef Dwernicki started his military career as an artillery cadet right before the Polish-Lithuanian Commonwealth was gobbled up by Austria, Prussia, and Russia. Joining Bonaparte's Polish army in 1806 he converted into a dashing cavalry leader, and was promoted to colonel for his skillful rear guard actions at Leipzig (1813). His military career continued with the Kingdom of Poland, where he wrote new cavalry regulations and made brigadier general in 1829. A portly fellow known for his love of fine food and spirits, Dwernicki also maintained excellent rapport with his troopers, and even the horses, who „....saved him from death several times." ${ }^{22}$

19 Puzrevskii, Wojna Polsko-Rossyjska, p. 46.

20 Germans, Austrians, Swedes, French Émigrés, and British officers served in the late 18 th to early 19th Century Russian armed forces. 'The Fanshawe family produced three generations of Russian generals! „Englishmen in Russian Service. The Fanshawes," in The United Service Magazine, Vol. 51 (May 1846): 85-86.

21 Russian sources call him Fedor Geismar Klementevitch. Friedrich Caspar von Geismar, Biographie des Generallieutenants Reichsfreiherrn Friedrich Caspar von Geismar, General der Cavalerie, Generaladjutant Sr. Maj. des Kaisers von Rußland (Munster: Druck und Verlag der Theissing'schen, 1860).

22 Józef Dwernicki, Pamiętniki (Lwów: Nakład i wydanie staraniem L. Plagowskiego, 1870). 
Dwernicki and his fellow generals faced several challenges in January/ February 1831. It was obvious Diebitsch was moving on W Warsaw with superior numbers. The rebel government, hoping to negotiate a settlement, refused to consider a preemptive strike and was slow to raise more troops. The tsar's refusal to offer concessions forced Polish leaders to authorize the draft of veterans and call for volunteers, but many of the new units nee ched training and lacked useful weapons.

Polish tradition held that in place of muskets, infantry could use scythes converted into pole arms. The architect Chrystian Piotr Aig ner even produced a booklet on the subject, Krótka nauka o kosach i pikach (Short Treatise on Pikes and Scythes), and called for more units of Kosynierzy (Scythmen). This was right after peasant yolunteers armed with scythes helped win the 1/94 battle of Racławice. By1831, these Kosynierzy were unlikely to produce victory As General Ignacy Prądzyński put it, ,....as for scythes or spades, this war proved once again that they were nothing compared to muskets and bayonets." ${ }^{23}$

Kosynierzy participated in only two major battles of the November Insurrection. Volunteer cavalrymen however, the Krakus, served in nearly every clash. Good horsemen, mainly equipped with sabers and a sprinkling of firearms, they formed 500-800 man regiments and were valuable assets on an 1831 battlefield. ${ }^{24}$

Both weapons and the tactics designed to make them effective, were dramatically different in 1831. Smart commanders made thein infantry, artillery and cavalry worked as a team, but due to the limitations of command and control, packed troops together in close formations. Firepower came from massed bodies shooting in volleys. This same body was an easy target for the opposition, and victory was often a matter of reloading one-shot muskets as rapidly as possible. Save for the Finnish Guard Jager Battalion, in 1831, not a single unit had rifles. Instead, cavalry used pistols or short barreled carbines, with longer muskets for the infantry all smoothbore. The post 1815 Russian army placed excessive value on fancy footwork for parades, and paid little attention to marksmanship beyond weapons

23 Ignacy Prądzyński, Pamietnik Historyczny, vol. I, p. 22. Scythes were still used by Polish rebels in 1863; their American counterparts considered issuing pikes to Confederate companies short on muskets.

24 Ignacy Prądzyński, Pamiętnik Historyczny, vol. I, p. 30. 
familiarization. The results were slow firing soldiers with weapons unlikely to cause severe casualties beyond 100 yards. Against opponents who could shoot faster, like Polish regulars, or move rapidly, like Krakus, torpid Russian columns could suffer painful stings. ${ }^{25}$

Cavalry battles, the forte of Geismar and Dwernicki, had their own special rules. Mounted troops were split into several categories. Ulans (lancers) usually had small nimble horses, and although their primary weapon gave them considerable reach, were designed for attacking flanks, plus scouting and skirmish warfare. Chasseurs rode larger horses, carried carbines and sabers and were deployed as battle cavalry. Cossacks, only found in the Russian army, made excellent scouts and could guard supply lines, but had little staying power on the battlefield. ${ }^{26}$

When rival horsemen attacked, there might be pistol or carbine fire, but bullets fired from smooth bores on a moving horse, were unlikely to hit unless discharged at point-blank range. As all were single-shot weapons, once fired, reloading was next to impossible during combat. An 1831 mounted clash was far more likely to be determined by cut and thrust weapons. They might not kill vast numbers of men, but some casualties, combined with a sense that enemy troopers were getting the upper hand, could rout a force off the battlefield. Horse size also played a part, heavy units like chasseurs sat on large horses, and a charge by such might smash through lines of ulans. Conversely, in an extended skirmish, ulan horses were easier to maneuver and had better endurance. Noted cavalry expert Captain Louis Nolan argued heavy horses seldom paid off as ,... history proves them to be more formidable in appearance than in reality." ${ }^{17}$

25 Robert Bruce, ct. al., Fighting Techniques of the Colonial Era, 1776-1914 (New York: St. Martin's Press, 2009) is a useful introduction.

26 Louis Edward Nolan, Cavalry. Its History and Tactics (London: Bosworth and Harrison, 1860 ) is available online. Captain Nolan provides an excellent, albeit highly opinionated look at period cavalry tactics.

27 Nolan, Cavalry, p. 64. 


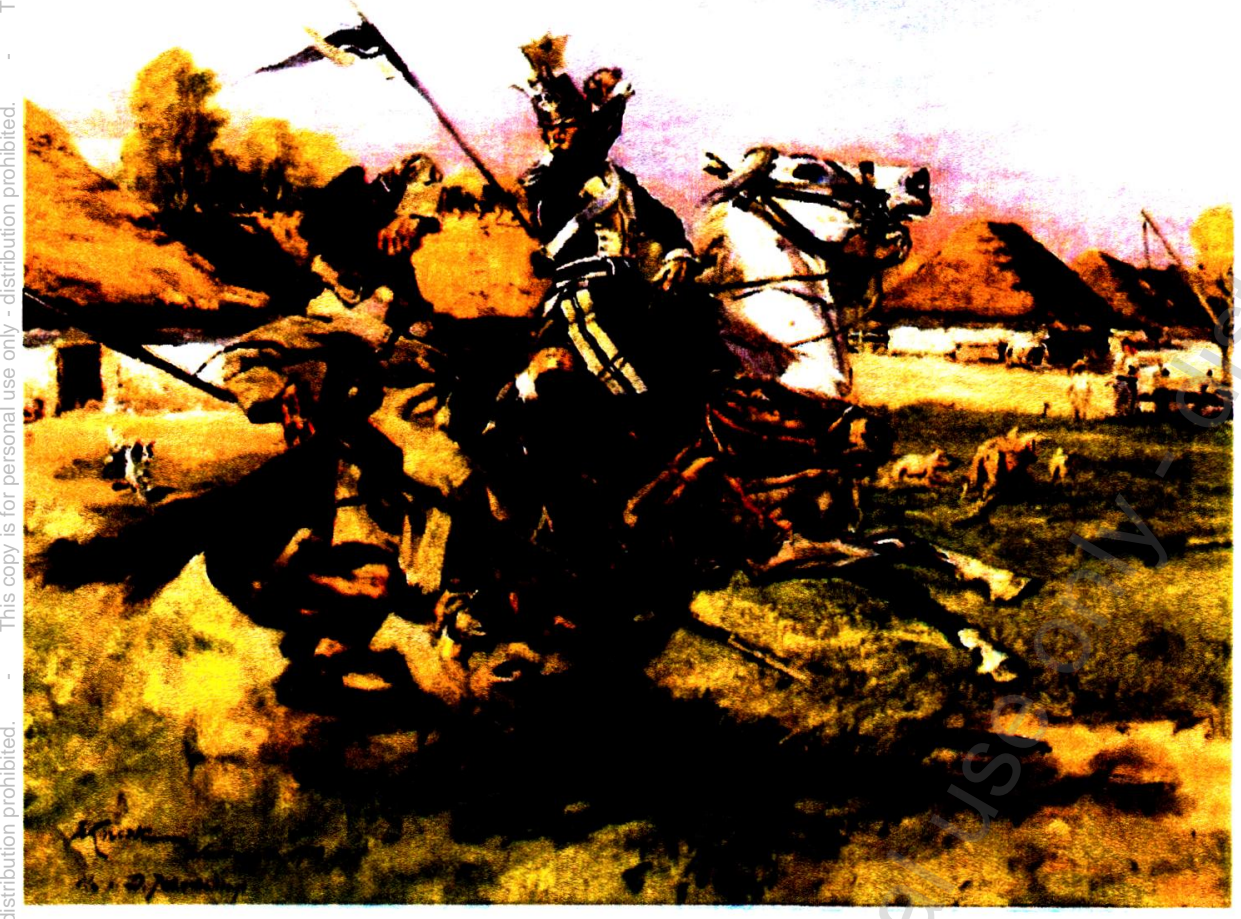

Ulan against Cossack by Wojciech Kossak (1900)

Ulans also gained an initial advantage from their weapons system. Lance heads focused the mass of horse and rider onto a narrow point that was guaranteed to penetrate even armor. Successful lance strikes would kill or seriously injure enemy riders or their horses. They were long enough to hit ground targets and even strike at infantry in defensive squares. Ulan tactics called for the riders to strike, ride through the enemy, then return, building up speed for another strike. Opponents armed with swords would strive to keep in contact, for ulans were at a disadvantage in extended hand-to-hand combat.

Good cavalry commanders were like modern fighter pilots, highly skilled, and aggressively pugnacious. Their situational awareness was not only familiarity with local terrain that could enhance offense or defense, but also ploughed fields or marshy soil that might pull off horseshoes, disabling mounts. Cavalry officers had to make the right decision quickly. Move at a trot to save horses' stamina, or order a charge to more rapidly cross ground and avoid extra volleys from reloading infantry or artillery? Save a few squadrons for a reserve, or send them all in to 
overwhelm the enemy line? Cavalry's speed required very rapid answers, and woe to the general who picked wrong, for his opponent would not. Do everything just right and your side had fresher horses, which could produce that last spurt of energy needed to turn a flank and possibly end the battle.

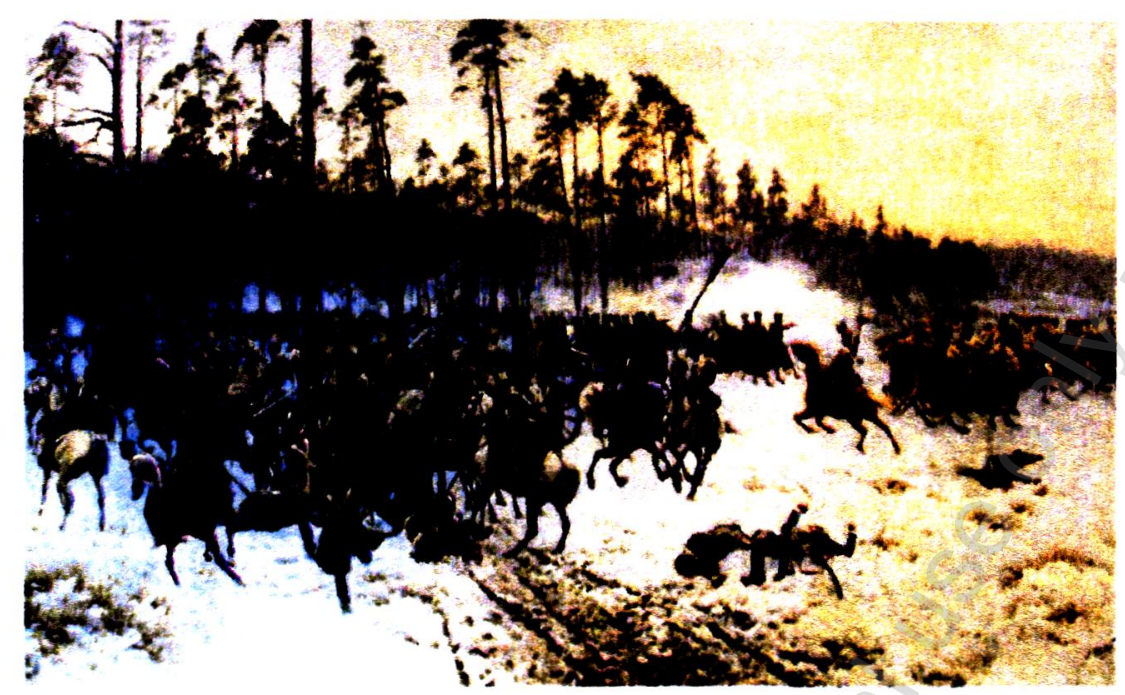

Battle of Stoczek by Jan Rosen (1890)

General Geismar understood these rules, but was also aware of what cold damp weather could do to both horses and men. His orders called for covering the army's immediate flank, dispersing partisans and gathering intelligence. Although his troopers fought minor skirmishes several times, reports from his Cossacks revealed no significant threats. On 11/12 February, Geismar dispersed his regiments into the many small villages near Seroczyn. Allowing his men to rest under shelter, while providing fodder for their mounts, made good sense considering the climate. $\mathrm{He}$ threw out patrols, creating a trip wire to warn of enemy actions..$^{28}$

28 Ignacy Prądzyński and A. Puzrevskii provide excellent details on the battle of Stoczek. A nice well illustrated modern account is Tomasz Strzeżk, Stoczek - Nowa Wies 1831 (Warszawa: Bellona, 2010). See also M. Kopczyński, Bitwa pod Stoczkiem (Warszawa, 2006); Dariusz.Małyszek, Bitwa pod Stoczkiem 14.11.1831 (Lublin, 2007); B. Pawłowski, Stoczek (Lwów, 1934). Sadly, Hordynski, a cavalry officer, and the only primary source in English, gets some of the battle confused with Polish actions against General Kreutz a few days later. 
In response, Poles were simultaneously massing for the defense of Warsaw, seeking information and hoping to upset Russian plans. Cavalry was the tool for both possibilities, and Józef Dwernicki was the man to command such a venture. $\mathrm{He}$ took 14 cavalry squadrons, a mix of ulans and chasseurs, three infantry battalions, and a battery of horse artillery. They crossed the still frozen Vistula, only after personal inspection by Dwernicki, and advanced to Mniszew, about 50 kilometers south of Warsaw. His orders provided considerable leeway, and he took this to mean he could hunt for isolated Russian parties and destroy them.

The Russians near Seroczyn became his target after locals reported their presence. They were spread out, and just far enough from Diebitsch, that a fast moving cavalry action might succeed before reinforcements could intervene. Dwernicki assumed there were a few hundred Russian troopers at the village of Stoczek (today Stoczek Łukowski). He arrived in the morning, but found the village empty. ${ }^{29}$

Dwernicki's surprise attack was foiled by scouting Cossacks who took one of his men prisoner. Cavalry battles ranged from the massed charge by brigades, or even divisions, to skirmishing patrols. The latter might not produce stirring pictures or epic poems, but they did gather intelligence, of which prisoners were the gold standard. In this case, Cossacks raced back to Geismar, and he was able to pull two squadrons from Stoczek, while organizing his division for combat. ${ }^{30}$

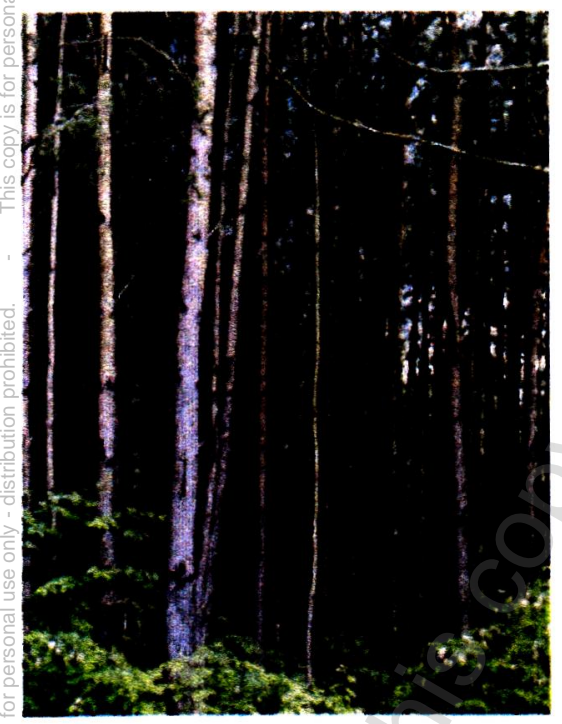

Photo taken by Dunn at Stoczek Pomnik in June 2013. It gives a good sense of the very thick nature of local forests, even if they were not very green in February

29 Puzyrevskii, pp. 47-48.

30 Wacław Tokarz, Wojna polsko-rosyjska 1830 i 1831 r. (Warszawa, 1993), pp. 167-170. 
Now it was Geismar's turn. For an aggressive general with a cavalry division, who underestimated the value of Poland's regular army, attack was his only thought, but the terrain between Seroczyn and Stoczek rendered the task difficult to execute. It was marshy ground mixed with thick belts of trees, sometimes replaced by low hills, and offering only two roads. Infantry could have crossed in between, but Russian chasseurs on their big horses would find any cross-country venture extremely difficult to impossible, and very wearing on the animals. ${ }^{31}$

Gesimar, confident a show of force would brush aside Polish resistance, opted for two attack columns, each supported by artillery. Both were to hit Stoczek simultaneously, but in the era before chronometers, combined with the lack of good maps, this was impossible to guarantee. Thus one column, a chasseur regiment supported by four cannon, left via the north road under Major General Aleksandr Paszkow, whose military career stretched back to 1804, all in mounted service. They traveled along a narrow trail through dense forests and had to cross a branch of the Świder River. Confined to this narrow approach, Paszkow's troopers formed a long column, and would require time to spread out into battle lines. ${ }^{32}$

A second chasseur regiment under Geismar, with six guns, took the road to Toczyska, and from there it was open, but uneven terrain to Stoczek. The deployment of the remainder of his division was problematic as there simply was no room to bring it along; a cavalry regiment, followed by an artillery battery, was a long column. Thus Geismar not only left half of his command at Seroczyn, but split the other half between himself and Paszkow. Before modern readers castigate, they might recall that cavalry victories went to the commander who could execute swift and forceful attacks. The Russians were not only confident this would happen, but also expected at least one column would have excellent chances of hitting their enemies in the flank. Under these circumstances, and considering terrain limitations, Geismar's plan makes sense. ${ }^{33}$

Dwernicki's scouts, along with reports of local peasants, guaranteed there would be no surprises. Still he faced a challenge, how to deploy his command for battle.

31 Pradzyński, vol. I, pg. 27.

32 Puzyrevskii, p. 48.

33 Ibidem. 
He had thirteen squadrons of highly trained regulars, some of the best cavalry in Europe. Then there were the six guns and three infantry battalions. The latter were a mixed bag, not all that well armed, and in some cases, new recruits. ${ }^{34}$

The Poles had crossed the Świder, and deployed about the village of Zgórznica. The settlement currently consists of only a few hundred people, which might explain why even though the battle was fought in front of Zgórznica, it is named after Stoczek. The village covered both roads used by the Russian columns. ${ }^{35}$

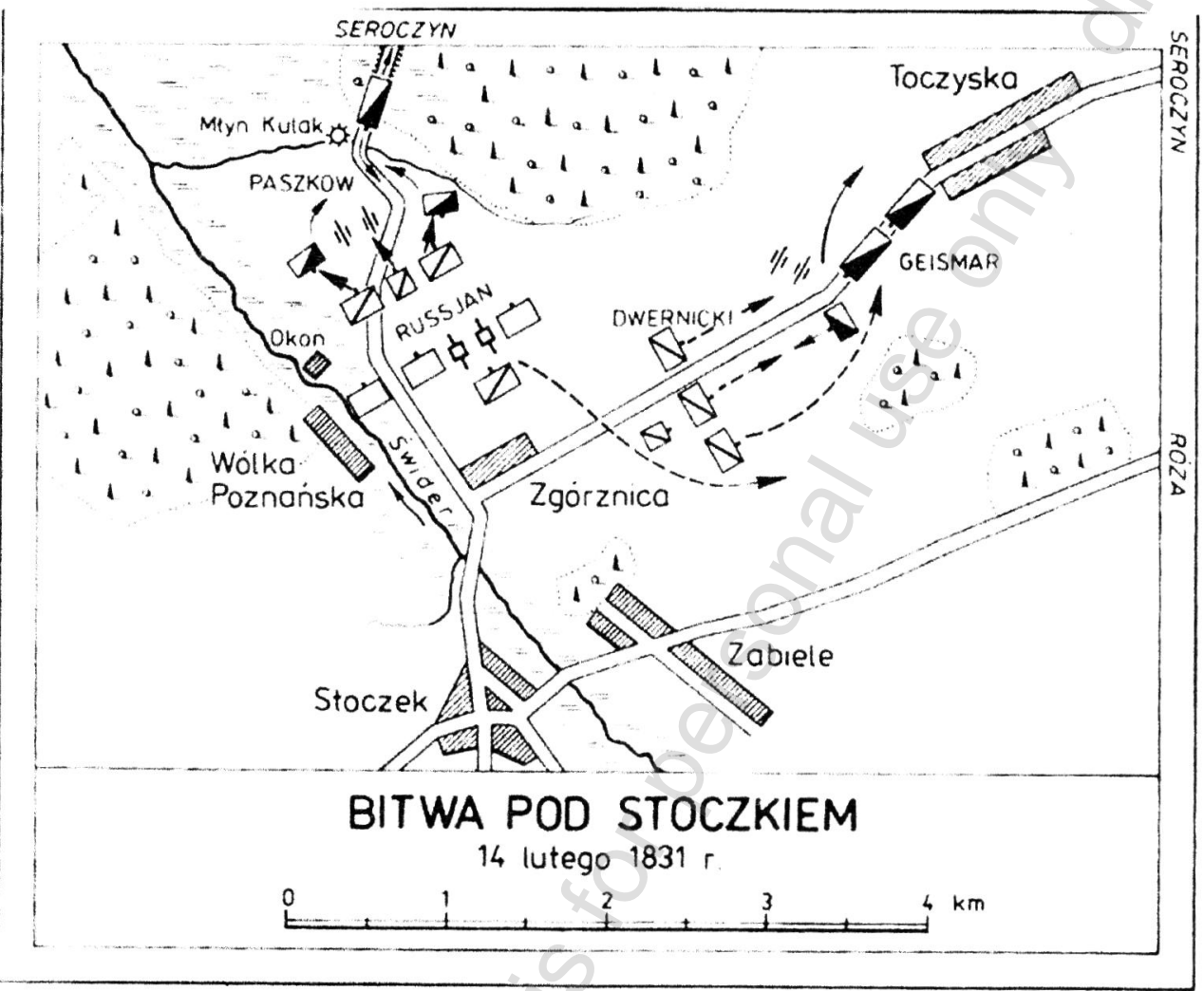

Source: Clipping file, John P. Dunn Collection.

Map of the battle of Stoczek

34 Pradzynski, vol. I, p. 34.

35 Tokarz, Wojna (1993), pp. 167-168. 
Placing his artillery on a hill that could cover these roads, Dwernicki backed them up with infantry on both flanks. This was his anchor, and the infantry were expected to defend the gunners, who would be free to attack enemy troopers, or conduct counter-battery fire. At the bottom of the hill, so as not to mask their artillery, Major Franciszek Russyan formed a line of ulans. A veteran of the Napoleonic Wars, his position was designed to attack any units exiting the road from Seroczyn. ${ }^{36}$

Eight chasseur squadrons lined up on the east side of Zgórznica. Elevations, some upwards of 174 meters, provided reverse slopes to hide them from plain view. A Krakus and two ulan squadrons formed Dwernicki's reserve - stationed immediately behind his guns. ${ }^{37}$

Paszkow started the battle early in the morning of 14 February. Polish artillery opened up on Paszkow's chasseurs, who had trouble forming lines due to gullies, trees, and marshy soil. This was painful, three Polish guns were 10-pounder licornes, hybrid gun-howitzers; the others regular three and six-pounders. This combination fired explosive and solid shot, resulting in a heavy fusillade on the Russians that made it even more difficult to transform from column to line. Despite all, Paszkow got two squadrons deployed, and his guns laid out between them.

Then Russyan sent his squadrons forwards before the Russian guns were completely set up, and enjoying considerable advantage in numbers had good expectations for victory. Russyan's charge slowed as his ulans went uphill, and at this point Paszkow made his last mistake. Russian chasseurs on their big horses were mainly designed for close combat. Charging downhill saber in hand, they would have a mass and momentum advantage over the smaller ulan horses. Instead, Paszkow ordered his men to fire their carbines. A good volley could have broken the ulans' charge, but poorly trained marksmen firing downhill from horseback needed to wait for point-blank range. The Russians fired too soon, and although Russyan was wounded, most shots missed. Then the ulans struck hard, spearing enemy horsemen and completely disrupting their deployment. The Russians fell back in such disorder, some unfortunate troopers fell into a pond, where both horses and

36 Puzyrevskii, pg. 47-48; Richard O. Spazier, Historja powstania narodu polskiego w roku 1830 i 1831, (Paris: J. Pinard, 1833), Vol. II, p. 26.

37 Puzyrevskii, pp. 47-48. 
riders drowned. Others ran through the artillery, insuring it would not have time to re-attach caissons for escape. ${ }^{38}$

Geismar came just in time to save Paszkow from complete destruction. His men had far better ground for deployment, and his six guns quickly started to batter the Polish infantry. Formed in dense formations to repel cavalry attacks while protecting their own artillery, they were perfect targets for Geismar's artillerymen. Casualties piled up, as Polish counter-battery efforts failed. Dwernicki realized he would not win a gun duel, and opted for a cavalry offensive instead. ${ }^{39}$

He sent orders to Russyan to pull back and engage Geismar, then shouting „Naprzód, stępem marsz!" (Forward at the trot), threw Polish chasseurs at the enemy. Next he took the reserves, and directed them in a flank attack. The result was Geismar's men getting hit on three sides. This final charge was the stuff of legend, with ulans skewering opponents on both flanks, while Dwernicki's adjutant cut down the Russian regimental commander. Geismar showed great courage, racing into the front ranks, attempting to rally his troopers. It was too late, and only excellent horsemanship kept him from capture or death. His retreating troopers carried many of the gunners' horses with them, so again the artillery was left behind. ${ }^{40}$

The Battle of Stoczek probably lasted thirty minutes. Dwernicki wisely kept his men in hand, as charging down the narrow roads to kill fleeing Russians could have set them up for the same problems that bedeviled Paszkow. Polish horses had also thrown lots of shoes in the muddy soil, and if not fixed, they could quickly go lame. Dwernicki listed 34 deaths at Stoczek, in exchange for 400 Russian troopers killed, 230 prisoners, and 10 captured artillery. No doubt every discarded saber, carbine and cartridge box were also picked off the battlefield. Russian sources admit to 280 casualties and eight guns lost at Stoczek, but General Andolenko admits the defeat created „...un retentissement considérable."

38 Puzyrevskii, p. 49, notes Geismar's chasseurs had just been issued lances, but with no time to train, had left these back in Russia. Spazier, Historja powstania..., Vol. II, p. 27.

39 Pradzynski, vol. I, p. 34; Puzyrevskii, p. 48; Spazier, Historja powstania..., Vol. II, p. 27-28.

40 Chłapowski, p. 11; Puzyrevskii, pp. 48-49; Soltyk, Vol. I, pp. 298-299.

41 Two guns were left behind for want of towing gear. Général Andolenko, Histoire de l'Armee Russe (Paris: Flammarion, 1967), p. 229; Brzozowski, p. 44; Neyfeld, p. 189; Pradzynski, vol. I, p. 34; Puzyrevskii, p. 48; Theodor Schiemann, [ed. and compiler], Erinnerungen von Alexander Lwowitsch Seeland aus der Polnischen Revolution von 1830/31 (Stuttgart: F. G. Sotta'schen, 1894), Vol. II, p. 95. 
Geismar lamented Stoczek as „...the unluckiest day in my life." ${ }^{42}$ Losing parts of two regiments, even worse artillery, were great embarrassments. Still, Geismar had enough men and cannon remaining to fight Dwernicki another day. Diebitsch's flank was not uncovered, and so from a tactical point of view, Stoczek was no calamity for Russia. On the political side, however, it was significant. This was the first major battle of the war, and Dwernicki's victory significantly increased morale back in Warsaw, where locals feared the approaching juggernaut. It was a revolutionary Valentine of the first order, delivered by Poland's number one ulan!

Despite limited rations, climate and Stoczek, Diebitsch got his men to the outskirts of Warsaw on 25 February and initiated the Battle of Olszynka Grochowska. Western sources often call it Grochow, but however you spell it, this was the largest European battle between Waterloo (1815) and the Crimean War (1855). This time it was Poland's infantry and artillery, including an innovative rocket battery, that played critical roles. Both sides suffered heavy casualties, and tactically it ended a draw. Strategically, it was a Polish victory. Warsaw, the nerve center of the revolution, was saved; Diebitsch forced to pull back to the east bedeviled by limited supplies plus an increasing sick roll. He did much better at Ostrołęka, on 26 May, but never saw any medal as the Field Marshal died on 10 June from the cholera Russian armies had carried back from the East. ${ }^{43}$

A week after Stoczek, Dwernicki, now promoted to major general, smacked three regiments of Cossacks and chasseurs at Nowa Wieś. With another set of captured Russian cannon, a New York paper claimed Dwernicki was now nicknamed the „...Cannon Provider, because every moment he is bringing in some fresh piece he has taken from the enemy" ${ }^{44}$ His last campaign was an April offensive into the Ukraine designed to raise partisans. Dwernicki took 7000 men and 12 guns running into General Theodor von Rüdiger's 11,000 Russians with 36 guns on the River Styr. ${ }^{45}$ Circumstances favored Dwernicki, as he had not crossed, and there was but one bridge. Using musket and cannon fire, he tossed back von Rüdiger's

42 Schiemann, Erinnerungen von Alexander..., Vol. III, p. 94.

43 For details see Tadeusz Stachowski, „Between Waterloo and the Alma. 'The PolishRussian War of 1831, Part I: Grochow," in History Today Vol. 29 (May 1979) No. 5: 310-317; and „....Part II: Ostrolenka," in History Today, Vol. 29 (June 1979) No. 6: 386-393.

44 "Poland," in Spirit of the Times [Batavia, N.Y.] (n.d., n.p.). Accessed online 24 March 2013.

45 In Russian, Fyodor V. Ridiger, a Livonian German who joined the Tsar's forces in 1800. 
determined assaults. This started the battle of Boremlen (18-19 April 1831), where Dwernicki had to repel several more attacks. Although both sides suffered similar casualties and were prepared for additional combat, this was not a viable option for the Poles. As a much larger Russian force moved to engage, Dwernciki took his troopers across the Austrian frontier where they were interned until the fall of $1831 .{ }^{46}$ By then, Warsaw was about to capitulate and the November Insurrection ended in early October. ${ }^{47}$

For men like Dwernicki, capitulation. was not an option. He made for Paris and was soon engaged in émigré politics. Jean Gigoux's 1833 portrait of the general makes clear he also maintained that love affair with food and spirits. Lionized as a revolutionary hero, he was the subject of Polenlieder (Songs for the Poles) like the Dwernicki March, which played as far west as Boston. ${ }^{48}$ Polish writers found him equally attractive, Gustav Ehrenberg used Stoczek as the battle reference for Gdy naród do boju (When a Nation Goes to War), while Wincenty Pol's Krakusy, in honor of the volunteer cavalrymen, starts with the well-known stanza...

\section{Grzmia pod Stoczkiem armaty,}

Btyszcza biate rabaty

\section{A Dwernicki na przedzie}

Na Moskala sam jedzie.

\section{(The cannons roar at Stoczek,}

The white lapels bright

And at the fore Dwernicki

rides alone against the Muscovite.)

Dwernicki retired to Austrian Poland in 1848, dying nine years later. How did his actions impact on military affairs and Polish history? What can one learn from Józef Dwernicki

46 Punctual, as only Hapsburgs could be, the Austrians returned all captured Russian gear to General von Rüdiger, but retained all weapons with Polish markings. „Brody, May 10," in Free Press (27 July 1831). Accessed online 24 March 2013.

47 Stefan Przewalski, „Bitwa pod Boremlem, Studia i materiały do historii wojskowości, in WMON, Vol. IX (1963) No. 2: 231-255.

48 „Dwernicki,” in Ernst Ortlepp (ed.), PolenLieder (Altenberg, 1831), p. 38; Charles Zeuncr, Two Grand Polish Marches (Boston: C. Bradlee, 1831). For more on German support for the Poles, see, Anneliese Gerecke, Das Deutsche Echo auf die Polnische Erhebung von 1830, (Wiesbaden: Otto Harrassowitz, 1964). 
and the battle of Stoczek? Although small, it provides several clear lessons. The need for good reconnaissance, that commanders must comprehend limitations terrain places on their movement, and how victory demands rapid and correct decisions. Dwernicki understood these well, and demonstrated top-notch leadership.

Modern Poles remember him as the dashing cavalier who won nearly every battle and set an example for future generations to fight no matter the odds, until Poland was free. It was a long wait, complete with more failed uprisings, but victory finally arrived in 1918. Modern Poland commemorated Dwernicki with numerous statues, street names, but possibly more dear to the general's heart, named the Second Ulan Regiment in his honor (2 Pułk Utanów Grochowskich im. Generała Józefa Dwernickiego), a tradition maintained by the Fourth Armored Cavalry Brigade into the 21st Century.

\section{References}

Bratkowski, Stanisław. Scelnes politiques de la reivolution polonaise. Liv. 3, Le premier reìgiment des Krakusses. Lyon: de Brunet, 1832.

Dwernicki, Józef. Pamiętniki jenerała Józefa Dwernickiego. Lwów: nakł. i wyd. Ludwika Plagowskiego, 1870.

Goczałkowski, Stanisław Wojciech Nepomucen. Pamieętniki ułana. Lwów: Księg. H. W. Kallenbacha, 1855.

Kopczyński, Michał. „Bitwa pod Stoczkiem,” in Rzeczpospolita. Vol. 17 (18/11/2006), No. 38: 4-15.

Leslie, R. F. Polish politics and the Revolution of November 1830. University of London, Athlone Press, 1956.

Puzrevskii, A. Wojna Polso-Rossyjska 1831 Roku. Trans. P. J. Bykowski. Warszawa: Tygodniowego, 1888.

R. de S. Notice biographique sur la vie et les travaux militaires de M. le G-al Dwernicki. Paris: en vente au bureau de la revue, 1844.

Strzeżek, Tomasz. Stoczek - Nowa Wieś 1831. Warszawa: Bellona, 2010.

Tokarz, Wacław. Wojna polsko-rosyjska 1830 i $1831 \mathrm{r}$. Warszawa, Wojskowy instytut naukowo-wydawniczy, 1930.

Trąbski, Maciej. Kawaleria Kroilestwa Polskiego, 1815-1830. Warszawa: Wydawnictwo DiG, 2011. 